\title{
Effect of dietary protein source on feed intake, growth, pancreatic enzyme activities and jejunal morphology in newly-weaned piglets
}

\author{
BY CAROLINE A. MAKKINK ${ }^{1}$, GEORGE PUIA NEGULESCU ${ }^{1,2}$, \\ QIN GUIXIN ${ }^{1,3}$ AND MARTIN W. A. VERSTEGEN ${ }^{1}$ \\ ${ }^{1}$ Agricultural University, Department of Animal Nutrition, Haagsteeg 4, 6708 PM Wageningen, \\ The Netherlands \\ ${ }^{2}$ Ministerul Agriculturii, Academia de Stiinte Agricole si Silvice Directia Generala Zooveterii, \\ Institutul de Biologie si Nutritie Animala, 8113 Balotesti sector Agricol Ilfov, Roemenië \\ ${ }^{3}$ Jilin Agricultural University, Department of Animal Science, Jingyue, Changchun, 130118, China
}

(Received 15 January 1993 - Revised 31 August 1993 - Accepted 14 January 1994)

\begin{abstract}
Seventy piglets with no access to creep feed were weaned at $28 \mathrm{~d}$ of age and fed on one of four diets based on either skimmed-milk powder (SMP), soya-bean-protein concentrate (SPC), soya-bean meal (SBM) or fish meal (FM). At $0,3,6$ and $10 \mathrm{~d}$ after weaning, piglets were killed and the pancreas and digesta from stomach and small intestine were collected, freeze-dried and analysed for dry matter (DM), $N$, and trypsin $(E C$ 3.4.21.4) and chymotrypsin $(E C$ 3.4.21.1) activities. Small-intestinal tissue samples were taken to examine gut wall morphology. Results indicated that dietary protein source affected postweaning feed intake, pancreatic weight, gastric $\mathrm{pH}$ and gastric protein breakdown, and pancreatic and jejunal trypsin and chymotrypsin activities. Post-weaning feed intake appeared to be an important factor in digestive development of newly-weaned piglets.
\end{abstract}

Pancreas: Dietary protein: Piglet

In pigs, digestive disorders are frequently encountered in the early post-weaning period. The protein digestive capacity of newborn piglets is adapted to the digestion of milk proteins. Proteins of plant origin are digested to a lesser extent than milk proteins resulting in poor performance when fed to newly-weaned piglets (Wilson \& Leibholz, 1981 $a, c$ ). It has been hypothesized (Jones, 1986) that this may be due to insufficient development of the pancreatic enzyme system, since many authors report a decline in enzyme activities following weaning (Lindemann et al. 1986; Owsley et al. 1986). However, the often impaired feed intake of newly-weaned piglets may also play a role in this respect.

The present experiment was designed to study the development of pancreatic enzymes of newly-weaned piglets in relation to dietary protein source and post-weaning feed intake.

\section{MATERIALS AND METHODS}

Seventy piglets with no access to creep feed during the suckling period were weaned at $28 \mathrm{~d}$ of age. Ten piglets were anaesthetized immediately after weaning (day 0), weighed and exsanguinated from the jugular veins and artery. During exsanguination the gastrointestinal tract was divided into four segments: stomach, duodenum (first $2 \mathrm{~m}$ from pylorus), ileum (last $2 \mathrm{~m}$ of the small intestine) and jejunum (remaining part of the small intestine). Digesta were collected quantitatively from the stomach and small intestine segments. Usually, death of the piglets occurred after the tissue and digesta samples had been collected. In 
fresh gastric digesta trichloroacetic acid (TCA)-precipitable protein was measured according to Ternouth et al. (1974). Digesta samples were weighed, the $\mathrm{pH}$ was measured and samples were frozen and stored at $-20^{\circ}$ before freeze-drying. The pancreas was excised, freed from adhering tissues, frozen and stored at $-20^{\circ}$ before freeze-drying. After freeze-drying, stomach and jejunum digesta samples were ground $(1 \mathrm{~mm})$ and analysed for dry matter and crude protein $(\mathrm{N} \times 6.25)$ content.

The TCA-precipitable protein fraction of the digesta comprises proteins and large peptides which cannot be absorbed by the intestinal wall without further hydrolysis (Souffrant, 1991). The ratio between TCA-precipitable protein (PP) and crude protein (CP) in gastric digesta was therefore calculated to determine the degree of gastric protein breakdown.

Trypsin (EC 3.4.21.4) and chymotrypsin (EC 3.4.21.1) activities were measured in jejunal digesta and in pancreatic tissue after freeze-drying (Bergmeyer, 1974; Van Baak et al. 1991).

The remaining sixty piglets were fed on one of four experimental diets based on either skimmed-milk powder (SMP), soya-bean-protein concentrate (SPC), soya-bean meal (SBM) or fish meal (FM). Diet compositions are given in Table 1. At 3,6 and $10 \mathrm{~d}$ after weaning, five piglets per diet were anaesthetized $1 \mathrm{~h}$ after feeding $100 \mathrm{~g}$ diet. Samples were collected, processed and analysed as described above (twenty piglets/d). At $6 \mathrm{~d}$ after weaning, duplicate tissue samples (approximately $5 \mathrm{~mm} \times 5 \mathrm{~mm}$ ) were taken from the proximal and distal jejunum immediately after removing the small intestine from the body cavity. These tissue samples were stored in $3 \mathrm{ml}$ cryotubes (Sanbio BV Biological Products, P.O. Box 540, NL-5400 AM, Uden The Netherlands), frozen immediately in liquid N and kept at $-70^{\circ}$ until further analysis. Sections were cut from the deep-frozen tissue samples within 2 weeks from collection using a cryostat (2800 Frigocut N; Reichert-Jung, Heidelberg, Germany), stained with toluidine blue and the lengths of ten villi and the depths of ten crypts were measured in each sample.

Analysis of variance was performed using the GLM procedure of SAS (Statistical Analysis Systems, 1990) for each day of sampling separately using the following model:

$$
Y_{i j}=\mu+D_{i}+\left(b_{1} \times \mathrm{FI}\right)+e_{i j},
$$

in which $Y_{i j}$ is the dependent variable, $\mu$ is the overall mean, $D_{i}$ is the effect of diet $(i=1$, $2,3,4), b_{1} \times \mathrm{FI}$ is the effect of feed intake (overall co-variable) and $e_{i j}$ is the error term.

Initially the effect of feed intake within diet was also tested, but this was found to be not significant for all variables except for chymotrypsin activity $3 \mathrm{~d}$ after weaning and was therefore eliminated from the model. Since the overall effect of feed intake on chymotrypsin activity on day 3 was not significant, the effects of diet and of feed intake within diet on chymotrypsin activities at day 3 were analysed according to the following model:

$$
Y_{i j}=\mu+D_{i}+\left(b_{1 i} \times \mathbf{F I}\right)+e_{i j}
$$

in which $Y_{i j}$ is the dependent variable (chymotrypsin activity at day 3 ), $\mu$ is the overall mean, $D_{i}$ is the effect of diet $(i=1,2,3,4), b_{1 i} \times \mathrm{FI}$ is the effect of feed intake within diet and $e_{i j}$ is the error term. From analysis of the data on feed intake during the first $3 \mathrm{~d}$ after weaning, two distinct patterns of feed intake emerged: several piglets consumed less than $50 \mathrm{~g}$ feed during these $3 \mathrm{~d}$, while the others ingested more than $100 \mathrm{~g}$. These two groups of piglets were called 'non-eaters' and 'eaters' respectively, and differences between these groups were analysed statistically. Post-hoc analysis of the effects of feed intake and diet on enzyme activities at day 3 was performed with the 'eaters' only.

To evaluate the development of gastrointestinal tissue weights after weaning the following model was used:

$$
Y_{i j}=\mu+W_{i}+e_{i j}
$$


Table 1. Composition of experimental diets $(\mathrm{g} / \mathrm{kg})$

\begin{tabular}{|c|c|c|c|c|}
\hline Diet... & SMP & SPC & SBM & $\mathbf{F M}$ \\
\hline \multicolumn{5}{|l|}{ Ingredient } \\
\hline Skimmed-milk powder* & 470.0 & - & - & - \\
\hline Soya-bean-protein concentrate $\dagger$ & - & $254 \cdot 0$ & - & - \\
\hline Soya-bean meal & - & - & $344 \cdot 0$ & - \\
\hline Fish meals & - & - & - & $213 \cdot 0$ \\
\hline Maize/wheat starch & $295 \cdot 0$ & $289 \cdot 0$ & $207 \cdot 8$ & $341 \cdot 7$ \\
\hline Dextrose & $133 \cdot 4$ & $109 \cdot 6$ & $109 \cdot 6$ & $109 \cdot 6$ \\
\hline Lactose & - & $225 \cdot 0$ & $225 \cdot 0$ & $225 \cdot 0$ \\
\hline Soya-bean oil & $20 \cdot 0$ & $22 \cdot 0$ & 27.5 & $20 \cdot 0$ \\
\hline Cellulose & $50 \cdot 0$ & $41 \cdot 0$ & 28.5 & $50 \cdot 0$ \\
\hline Ground limestone & $7 \cdot 5$ & $14 \cdot 5$ & $14 \cdot 5$ & $7 \cdot 5$ \\
\hline $\mathrm{CaHPO}_{4}$ & $5 \cdot 0$ & $22 \cdot 5$ & $21 \cdot 0$ & $2 \cdot 5$ \\
\hline $\mathrm{NaCl}$ & $3 \cdot 0$ & 3.0 & 3.0 & $3 \cdot 0$ \\
\hline $\mathrm{KHCO}_{3}$ & 3.0 & 2.0 & - & $11 \cdot 0$ \\
\hline $\mathrm{NaHCO}_{3}$ & $1 \cdot 0$ & $2 \cdot 0$ & $4 \cdot 0$ & $4 \cdot 0$ \\
\hline L-Lysine $\mathrm{HCl}$ & - & $1 \cdot 4$ & 1.6 & - \\
\hline DL-Methionine & $1 \cdot 1$ & $2 \cdot 2$ & $2 \cdot 1$ & $1 \cdot 0$ \\
\hline L-Threonine & - & 0.8 & 0.4 & 0.7 \\
\hline Vitamin and mineral premix & $10 \cdot 0$ & $10 \cdot 0$ & $10 \cdot 0$ & $10 \cdot 0$ \\
\hline $\mathrm{Cr}_{2} \mathrm{O}_{3}$ & $1 \cdot 0$ & $1 \cdot 0$ & 1.0 & $1 \cdot 0$ \\
\hline \multicolumn{5}{|l|}{ Calculated contents } \\
\hline Dry matter & 938.0 & 939.5 & 933.0 & 938.8 \\
\hline Crude protein $(\mathrm{N} \times 6.25)$ & $162 \cdot 1$ & $164 \cdot 4$ & 163.8 & 162.2 \\
\hline Ether extract & $25 \cdot 1$ & $24 \cdot 4$ & 31.8 & 35.4 \\
\hline Crude fibre & $49 \cdot 5$ & $49 \cdot 5$ & 50.2 & $49 \cdot 5$ \\
\hline Inorganic matter & $54 \cdot 6$ & 57.9 & 59.9 & $50 \cdot 5$ \\
\hline Net energy $(\mathrm{MJ} / \mathrm{kg})$ & $10 \cdot 20$ & $10 \cdot 25$ & $10 \cdot 21$ & $10 \cdot 49$ \\
\hline \multicolumn{5}{|l|}{ Analysed contents } \\
\hline Dry matter & $912 \cdot 1$ & $924 \cdot 1$ & $927 \cdot 0$ & $925 \cdot 3$ \\
\hline Crude protein $(\mathrm{N} \times 6.25)$ & 163.9 & $169 \cdot 7$ & $145 \cdot 5$ & $148 \cdot 4$ \\
\hline Buffering capacity $\|$ & $7 \cdot 2$ & $6 \cdot 4$ & $6 \cdot 4$ & 7.7 \\
\hline Pellet hardness & $14 \cdot 25$ & $18 \cdot 00$ & 3.88 & 4.38 \\
\hline
\end{tabular}

SMP, skimmed-milk powder; SPC, soya-bean-protein concentrate; SBM, soya-bean meal; FM, fish meal.

* Crude protein, $351 \mathrm{~g} / \mathrm{kg}$; trypsin inhibitor activity, $<0.5 \mathrm{mg}$ inhibited trypsin $/ \mathrm{g}$ product; antigens, 2 titre $\log _{2}$; protein dispersability index, 0.93 .

† Soycomil P, Loders Croklaan BV, P.O. Box 4, 1520 AA Wormerveer, The Netherlands. Crude protein, $639 \mathrm{~g} / \mathrm{kg}$; trypsin inhibitor activity, $1.3 \mathrm{mg}$ inhibited trypsin/g product; antigens, < 1 titre $\log _{2}$; protein dispersability index, 0.04 . Heat treated.

$\ddagger$ Crude protein, $392 \mathrm{~g} / \mathrm{kg}$; trypsin inhibitor activity; $1.6 \mathrm{mg}$ inhibited trypsin/g product; antigens, 5 titre $\log _{2}$; protein dispersability index, 0.12 . Heat treated.

$\S$ Crude protein, $692 \mathrm{~g} / \mathrm{kg}$; trypsin inhibitor activity; $1.1 \mathrm{mg}$ inhibited trypsin/g product; antigens, 2 titre $\log _{2}$; protein dispersability index, 0.10 .

$\|$ Volume $(\mathrm{ml}) 1 \mathrm{M}-\mathrm{HCl}$ needed to reach $\mathrm{pH} 4.00$ in a suspension of $20 \mathrm{~g}$ feed in $100 \mathrm{ml}$ demineralized water.

Tा Determined by Kahl Pellet Tester (Amandus Kahl Nachf. Maschinenfabrik, 2057 Reinbek, Hamburg), Pellet hardness expressed in kgf.

in which $Y_{i j}$ is the dependent variable (gastric or intestinal tissue weight), $W_{i}$ is the day after weaning $(i=0,3,6,10)$ and $e_{i j}$ is the error term.

\section{RESULTS}

Feed intake and growth

At weaning piglets were $28 \mathrm{~d}$ of age and had a mean live weight of $7 \cdot 1 \mathrm{~kg}$ (SD 1.3, $n 70)$. Feed intake during the first $3 \mathrm{~d}$ post-weaning was affected by dietary protein source (Table 2 ). 
Table 2. Effect of diets containing skimmed-milk powder (SMP), soya-bean-protein concentrate $(S P C)$, soya-bean meal $(S B M)$ or fish meal $(F M)$ on average daily feed intake (FI) and average daily growth $(A D G)$ of newly-weaned piglets*

(Values are least square means)

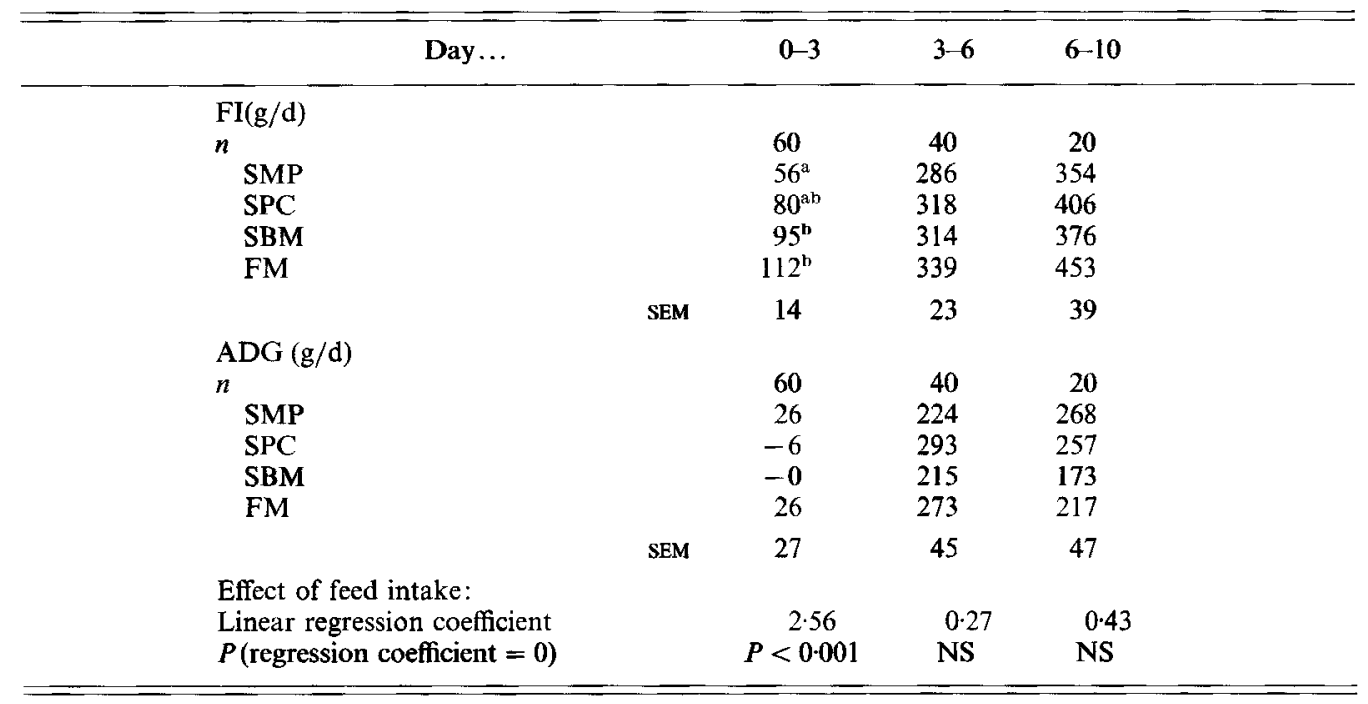

NS, not significant.

a,b Least square means within a column without a common superscript were significantly different $(P<0-05)$.

* For details of diets and procedures, see Table 1 and pp. 354-355.

Pellets of the SMP diet were harder than pellets of the SBM and FM diets (Table 1) and feed intake on the SMP diet was lower during the first $3 \mathrm{~d}$ post-weaning. Feed intake on the SPC diet was intermediate although pellets of this diet were very resistant to crumbling. Ten piglets out of sixty (five on SMP, three on SPC and two on SBM) consumed less than $50 \mathrm{~g}$ feed during the first $3 \mathrm{~d}$ after weaning. From $3 \mathrm{~d}$ after weaning, feed intake was similar for all diets. Average daily gain was not affected by dietary protein source (Table 2). During the first $3 \mathrm{~d}$ after weaning, growth was very variable between piglets and feed intake strongly affected average daily gain. From $3 \mathrm{~d}$ after weaning, no effect of feed intake on growth was found (Table 2).

\section{Tissue weights}

Dietary protein source did not influence the weight of the stomach and the small intestine (absolute and relative to live weight) after weaning (Table 3). The relative weight of the small-intestinal tissue decreased during $3 \mathrm{~d}$ after weaning (Fig. 1). The relative weight of gastric tissue increased gradually after weaning (Fig. 1).

Pancreatic weight was clearly affected by dietary protein source. At day 3 the weight of the pancreas ( $\mathrm{g} / \mathrm{kg}$ live weight) was higher for piglets fed on SPC and FM than for piglets fed on SBM. At day 6 the pancreatic weight $(\mathrm{g})$ was high for piglets fed on SPC and SMP and low for piglets fed on FM. At day 10 the relative weight of the pancreas was high for piglets fed on SPC and low for piglets on the FM diet (Table 3). At days 6 and 10 postweaning, small-intestinal tissue weight was positively affected by preceding feed intake. At day 6 the same was found for the weight of the pancreas (absolute and relative). 


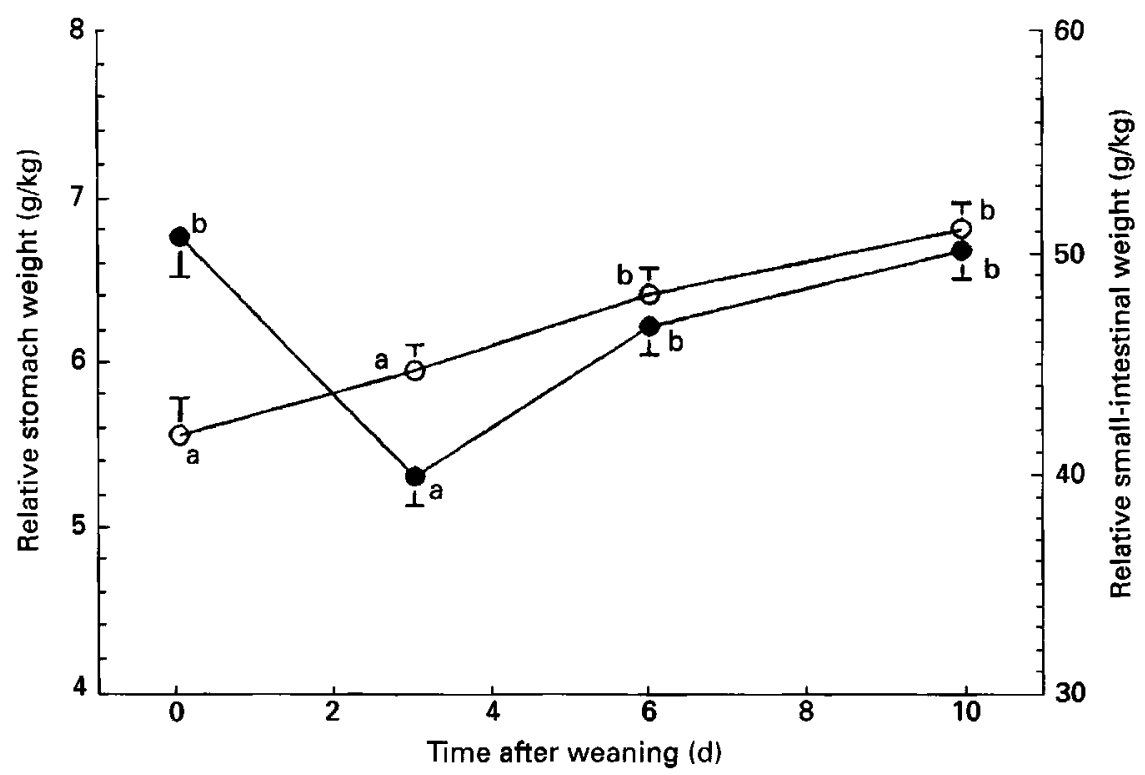

Fig. 1. Development of relative stomach $(O)$ and small intestinal $(O)$ tissue weights $(\mathrm{g} / \mathrm{kg}$ live weight) after weaning. Values are least square means, with their standard errors indicated by vertical bars. Data points within a tissue carrying different letters were significantly different $(P<0.05)$.

\section{Digesta $p H$}

At days 3 and 6 after weaning, digesta $\mathrm{pH}$ was not affected by dietary protein source. At day 3 , jejunum $\mathrm{pH}$ was positively related to feed intake (Table 4). At day 10 , piglets fed on the soya-bean diets had lower gastric $\mathrm{pH}$ than piglets fed on the FM diet.

\section{Gastric PP: CP ratio}

At day 10 after weaning the PP: CP ratio in the stomach digesta was significantly lower for piglets fed on the FM diet than for piglets on SPC, indicating a higher degree of gastric protein breakdown in gastric digesta at the time of slaughter with piglets fed on the FM diet (Table 4).

\section{Gut wall morphology}

None of the piglets killed at day 6 post-weaning had finger-shaped villi. All villi were tongue- and leaf-shaped (Kik et al. 1990). No effects of dietary protein source on villus lengths or crypt depths were found. Jejunal villus lengths (proximal and distal) and distal crypt depths at day 6 after weaning were positively related to feed intake (Table 4).

\section{Enzyme activities}

Enzyme activities are presented in Table 5 (trypsin) and in Table 6 (chymotrypsin).

Four out of twenty piglets sampled at day 3 post-weaning had consumed less than $10 \mathrm{~g}$ feed daily and these piglets were analysed separately because they ('non-eaters') were distinctly different from the other piglets with respect to enzyme activities. Non-eaters had higher enzyme activities in pancreatic tissue and higher chymotrypsin activities/g jejunal digesta than piglets that did consume appreciable amounts of feed after weaning ('eaters'; Table 7). Trypsin activity: chymotrypsin activity in pancreas and jejunum was higher for 'eaters' than for 'non-eaters' (Table 7). Therefore, the 'non-eaters' were not included in the further statistical analysis of piglets sampled at day 3 after weaning (Tables 5 and 6 ). 


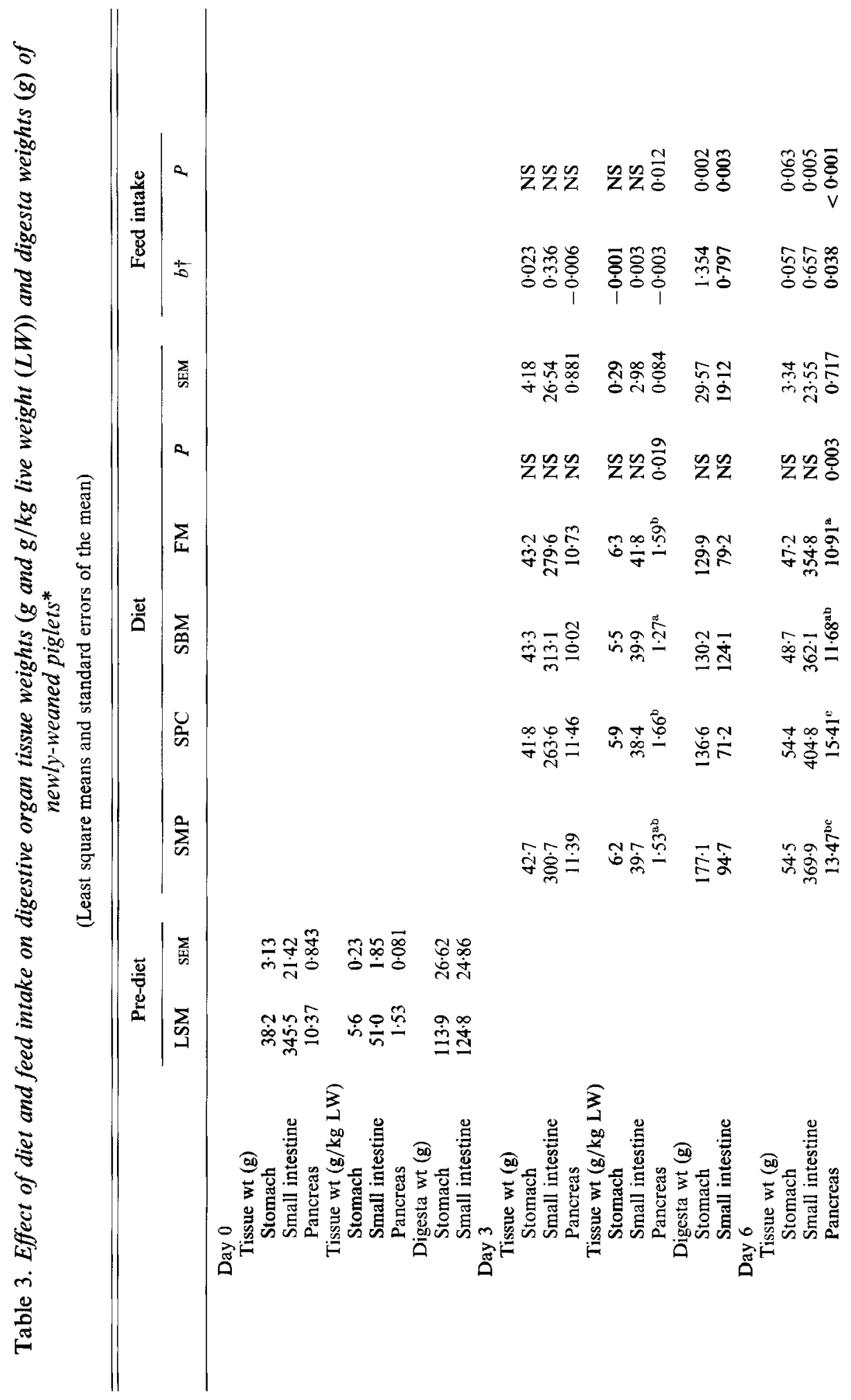


PROTEIN TYPE AND DEVELOPMENT IN PIGS

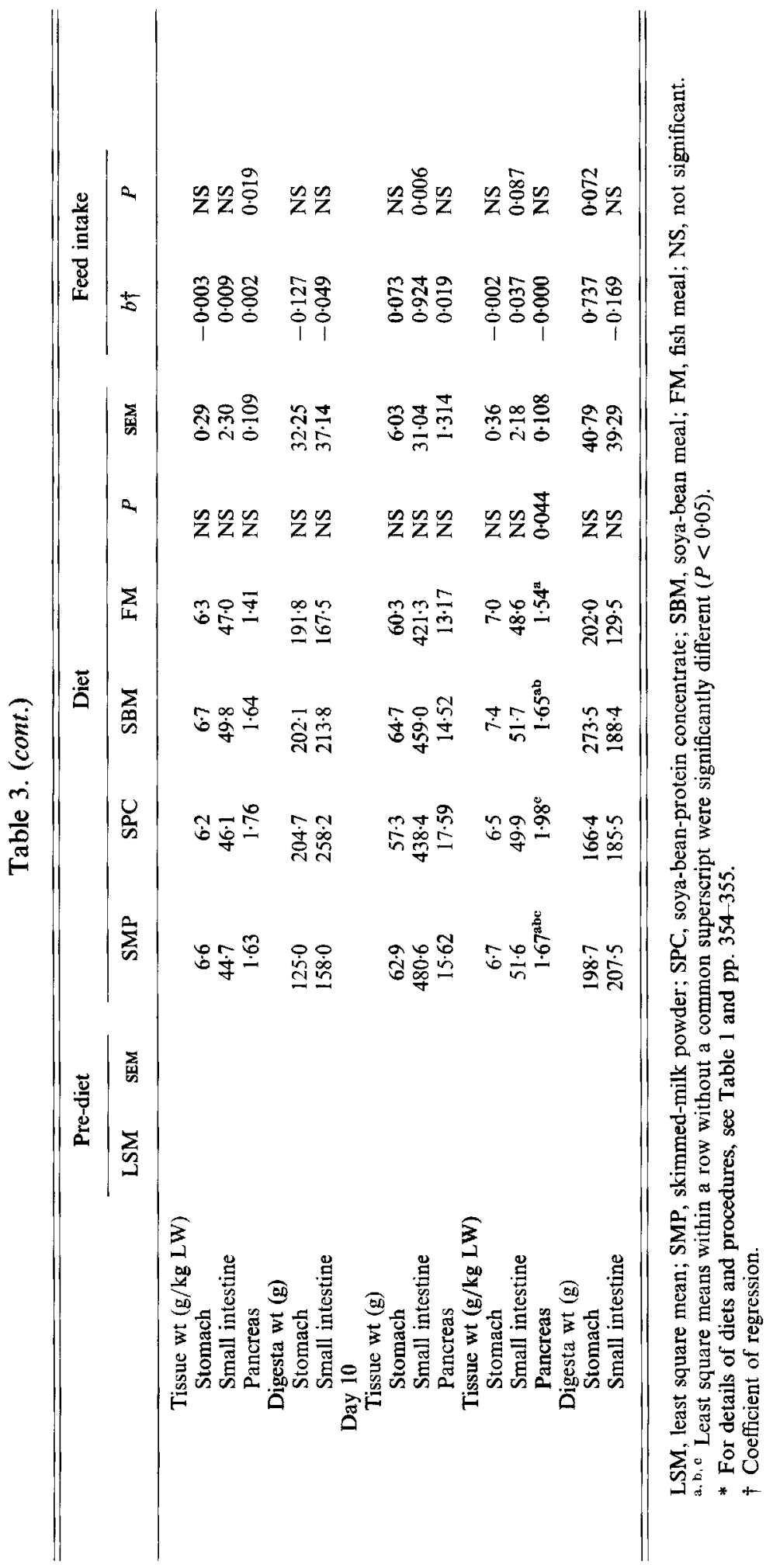


ริ

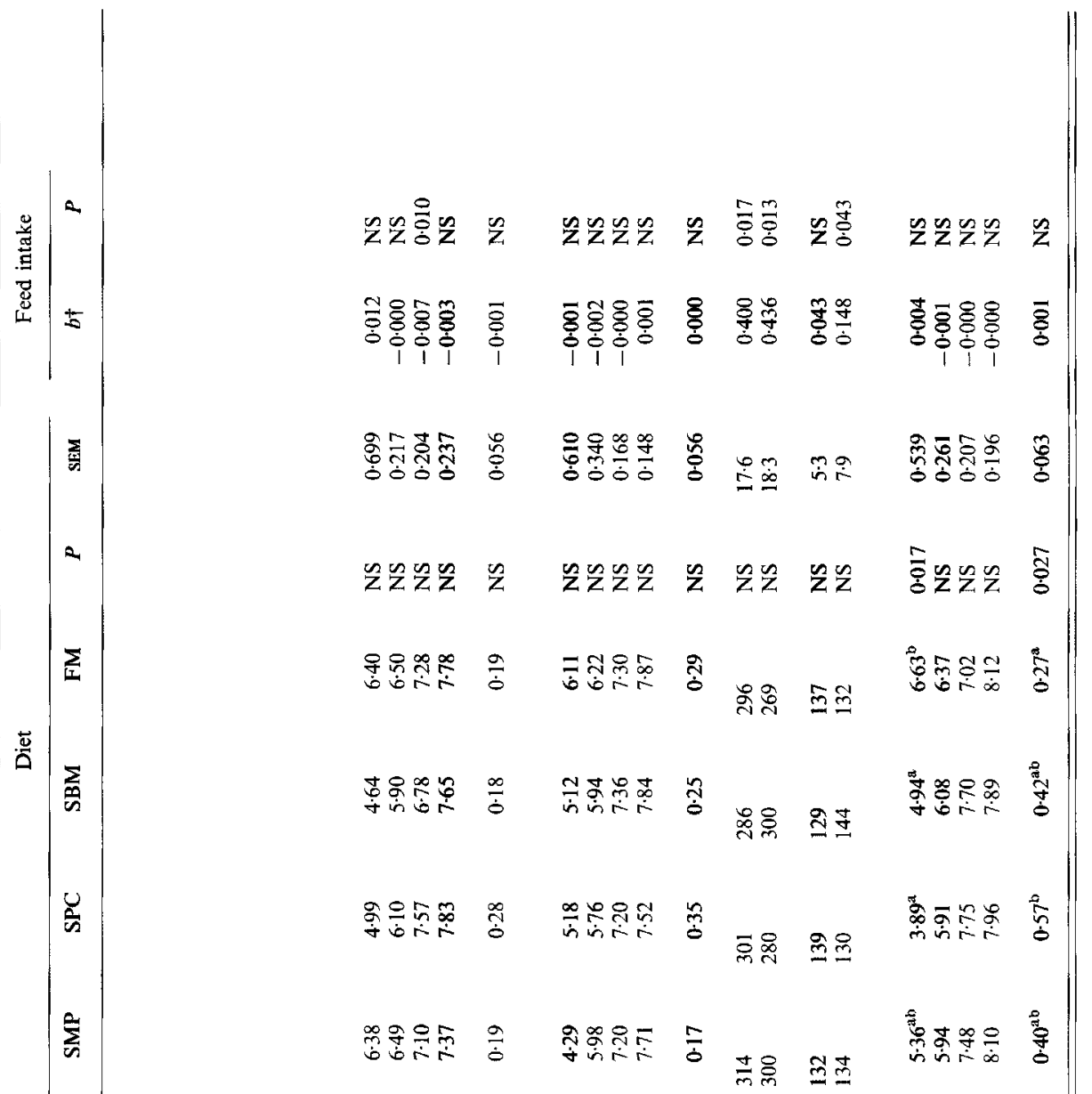

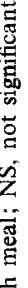

0

3

녕

ड़ 
PROTEIN TYPE AND DEVELOPMENT IN PIGS

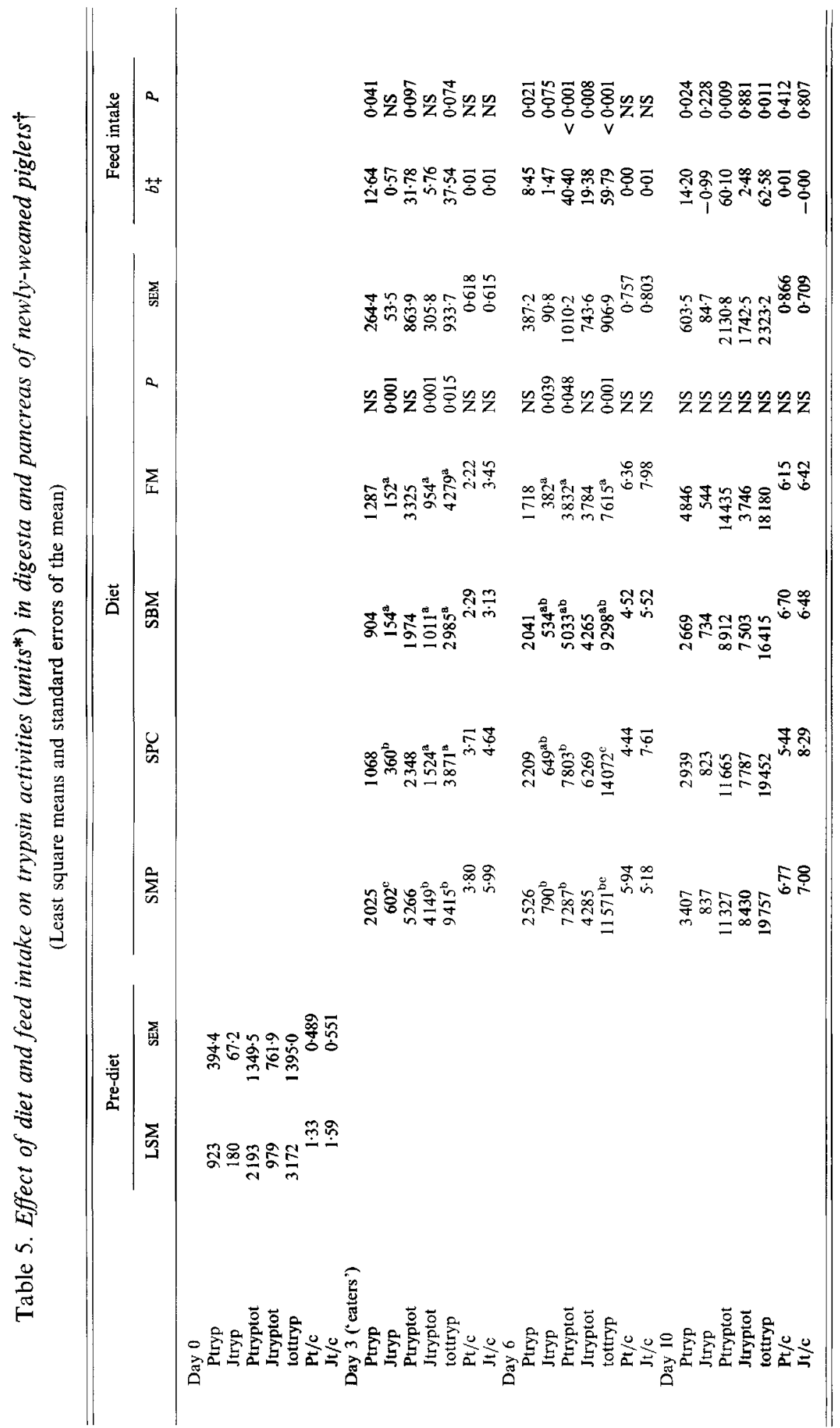

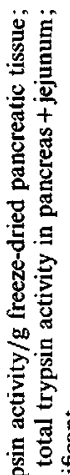

츨 홀 ํํㄹ 范

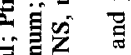
急喓 至.

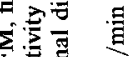

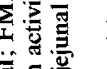
$\frac{2}{2} \cdot \frac{5}{5}$ 출일 新焉过

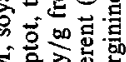
思产产密

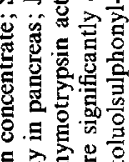

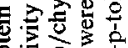

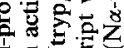

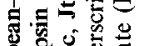
E气言要

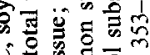
के ڤ.

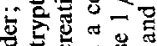
可参泀-

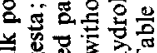

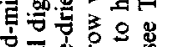

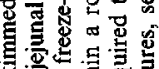

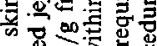

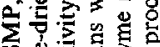

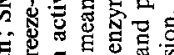

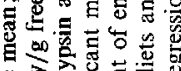

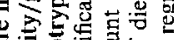
蛋 क्ष

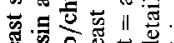

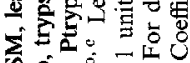


Table 6. Effect of diet and feed intake on chymotrypsin activities (units $\left.{ }^{*}\right)$ in digesta and pancreas of newly-weaned piglets $\dagger$

(Least square means and standard errors of the mean)

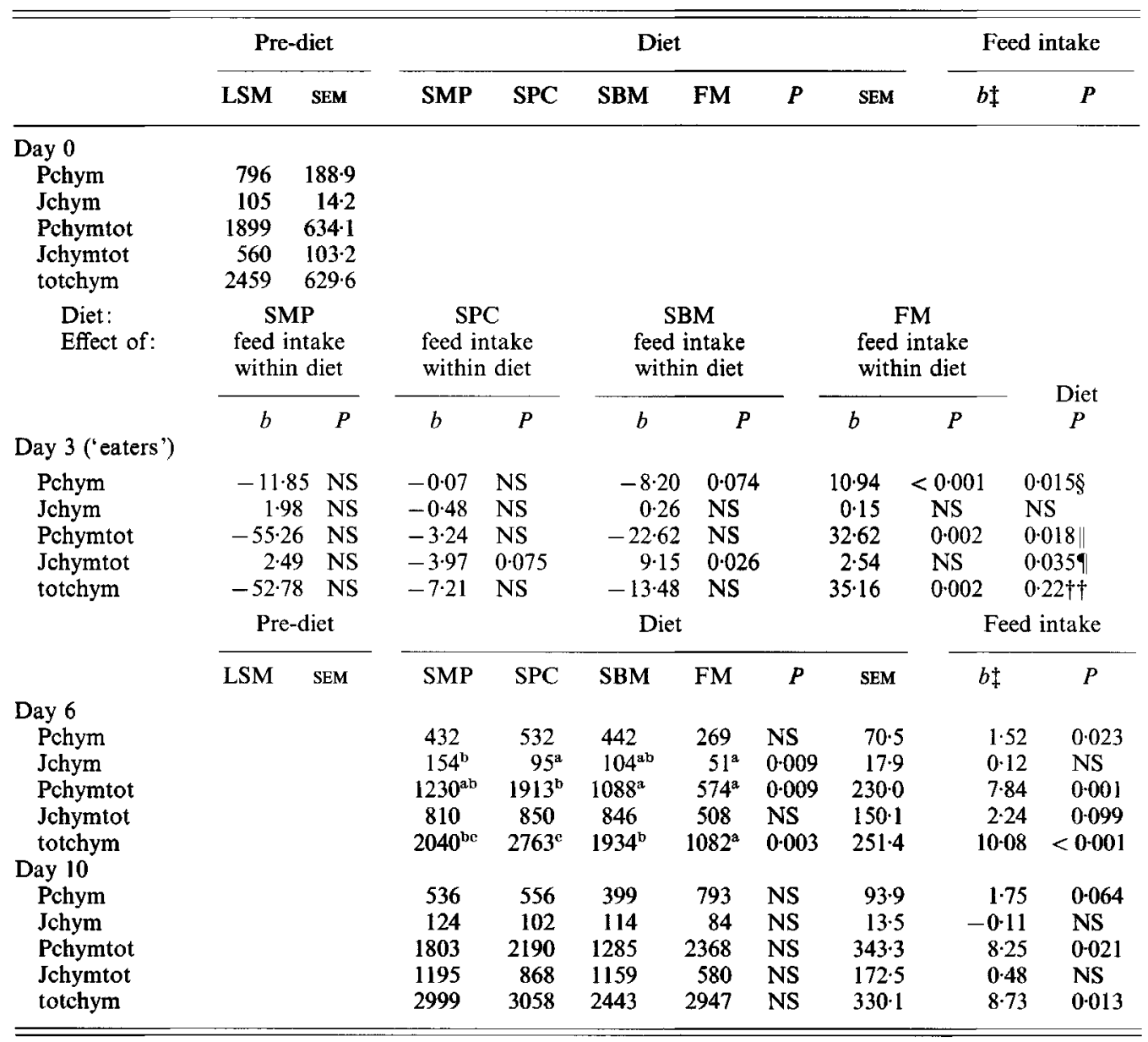

LSM, least square mean; SMP, skimmed-milk powder; SPC, soya-bean-protein concentrate; SBM, soya-bean meal; FM, fish meal; Pchym, chymotrypsin activity/g freeze-dried pancreatic tissue; Jchym, chymotrypsin activity/g freeze-dried jejunal digesta; Pchymtot, total chymotrypsin activity in pancreas; Jchymtot, total chymotrypsin activity in jejunum; totchym total chymotrypsin activity in pancreas + jejunum; NS, not significant.

a, b.o Least square means within a row without a common superscript were significantly different $(P<0.05)$.

* 1 unit $=$ amount of enzyme required to hydrolyse $1 \mu \mathrm{mol}$ substrate $(N$-benzoyl-L-tyrosine ethyl ester $) / \mathrm{min}$ at $25^{\circ}$ and $\mathrm{pH} 7 \cdot 8$.

$\uparrow$ For details of diets and procedures, see Table 1 and pp. 353-355.

$\ddagger$ Coefficient of regression.

$\S \mathrm{FM}>\mathrm{SPC}$.

$\| \mathrm{FM}>\mathrm{SPC}, \mathrm{FM}>\mathrm{SBM}$.

I $\mathrm{SMP}>\mathrm{FM}$.

+ FM $>$ SPC, FM $>$ SBM.

At day 3 , trypsin activity in the jejunum was affected by protein source (Table 5). The highest trypsin activity was found with piglets fed on SMP and the lowest activity was noticed in piglets fed on SBM and FM.

A significant effect of feed intake within diet on chymotrypsin activity at day 3 post- 
Table 7. Comparison of trypsin and chymotrypsin activities (units)* in the pancreas and jejunal digesta from newly-weaned piglets that consumed more than $100 \mathrm{~g}$ feed/d ('eaters') or less than $50 \mathrm{~g}$ feed/d ('non-eaters') in the $3 \mathrm{~d}$ immediately after weaning $\dagger$

(Least square means with their standard errors)

\begin{tabular}{|c|c|c|c|c|c|}
\hline \multirow[b]{2}{*}{ Day 3} & \multicolumn{2}{|c|}{$\begin{array}{l}\text { 'Eaters' } \\
(n 15)\end{array}$} & \multicolumn{2}{|c|}{$\begin{array}{c}\text { 'Non-eaters' } \\
(n 4)\end{array}$} & \multirow[b]{2}{*}{$P$} \\
\hline & LSM & $\mathbf{S E}$ & LSM & SE & \\
\hline \multicolumn{6}{|c|}{ Trypsin activity: } \\
\hline Ptryp & 1225 & 177 & 3029 & 342 & $<0.001$ \\
\hline Jtryp & 268 & 51 & 150 & 98 & NS \\
\hline Ptryptot & 2963 & 500 & 9239 & 969 & $<0.001$ \\
\hline Jtryptot & 1547 & 284 & 370 & 549 & 0.074 \\
\hline tottryp & 4510 & 660 & 9608 & 1277 & 0.003 \\
\hline $\mathrm{Pt} / \mathrm{c}$ & $2 \cdot 85$ & $0-31$ & 1.08 & 0.61 & 0.019 \\
\hline $\mathrm{Jt} / \mathrm{c}$ & $4 \cdot 02$ & $0 \cdot 36$ & 0.84 & 0.70 & 0.001 \\
\hline \multicolumn{6}{|c|}{ Chymotrypsin activity: } \\
\hline Pchym & 467 & 70 & 2868 & 135 & $<0.001$ \\
\hline Jchym & 63 & 10 & 150 & 19 & $<0.001$ \\
\hline Pchymtot & 1138 & 278 & 8992 & 539 & $<0.001$ \\
\hline Jchymtot & 369 & 52 & 199 & 100 & NS \\
\hline totchym & 1507 & 274 & 9191 & 530 & $<0.001$ \\
\hline
\end{tabular}

LSM, least square mean; Ptryp, trypsin activity/g freeze-dried pancreatic tissue; Jtryp, trypsin activity/g freezedried jejunal digesta; Ptryptot, total trypsin activity in pancreas; Jtryptot, total trypsin activity in jejunum; tottryp, total trypsin activity in pancreas +jejunum; Pchym, chymotrypsin activity $/ g$ freeze-dried pancreatic tissue; Jchym, chymotrypsin activity/g freeze-dried jejunal digesta; Pchymtot, total chymotrypsin activity in pancreas; Jchymtot, total chymotrypsin activity in jejunum; totchym, total chymotrypsin activity in pancreas + jejunum; Ptc/, Ptryp/Pchym; Jt/c, Jtryp/Jchym; NS, not significant.

$* 1$ unit $=$ the amount of enzyme required to hydrolyse $1 \mu \mathrm{mol}$ substrate $/ \mathrm{min}$ at $25^{\circ}$.

$\dagger$ For details of diets and procedures, see Table 1 and pp. 353-355.

weaning was found (Table 6). Chymotrypsin activity in pancreatic tissue was positively related to feed intake only for piglets on the FM diet. At day 3, pancreatic chymotrypsin activity and total chymotrypsin activity (pancreas + jejunum) were higher for the FM-fed piglets than for the soya-bean-fed piglets. Jejunal chymotrypsin activity was higher for piglets fed on SMP than for piglets fed on FM.

At day 6, enzyme activities in pancreatic tissue and jejunal chyme were lowest for piglets fed on the FM diet compared with the other diets. Total enzyme activities (pancreas + jejunum) were highest for the SPC-fed piglets. Trypsin activity/g freeze-dried jejunal digesta was lower in piglets fed on FM than in piglets fed on SMP (Table 5). Chymotrypsin activity/g freeze-dried jejunal chyme was lower in piglets fed on FM and SPC than in piglets fed on SMP. Total enzyme activities in the pancreas were highest for SPC-fed piglets and lowest for FM-fed piglets (Tables 5 and 6). Total trypsin and chymotrypsin activities in pancreas + jejunum at day 6 were positively related to post-weaning feed intake. This was mainly due to the strong relationship between feed intake and pancreatic enzyme activities (total and per $\mathrm{g}$ pancreatic tissue).

At day 10 after weaning no effects of dietary protein source on either trypsin or chymotrypsin activities were found. In particular, the pancreatic trypsin and chymotrypsin activities seemed to increase sharply for the FM diet, resulting in equal pancreatic enzyme activities for all four diets. 


\section{DISCUSSION \\ Feed intake and growth}

The low feed intake of piglets on the SMP diet may be related to the physical form of the feed. Feeds containing large amounts of skimmed-milk powder are difficult to pellet and will therefore result in hard pellets which are not readily accepted by young piglets (Jensen, 1966; Liptrap \& Hogberg, 1991).

Piglets fed on the SMP diet consumed less feed during the first $3 \mathrm{~d}$ post-weaning than piglets fed on the FM diet (Table 2) and at the same time had higher gastric digesta weights (Table 3). This may indicate that emptying of gastric digesta was faster in piglets fed on FM, as was also found by Sève \& Laplace (1975) with early-weaned piglets fed on solid diets containing milk and fish proteins. This could have resulted in a more regular feed intake for piglets fed on the FM diet.

The differences in feed intake between diets did not result in differences in average daily gain during the first $3 \mathrm{~d}$ post-weaning. Piglets fed on the diets based on animal proteins (SMP and FM) seemed to gain some live weight during the first $3 \mathrm{~d}$ post-weaning although the differences between diets were not significant. Average daily gain agreed with the results of Bark et al. (1986), who studied feed intake during the first week post-weaning in piglets weaned at $21 \mathrm{~d}$ of age.

\section{Tissue weights}

The relative weight of the empty stomach increased gradually after weaning, while the relative weight of the small-intestinal tissue decreased from weaning until $3 \mathrm{~d}$ after weaning. The same trends were found by Kelly et al. (1991 a) with piglets weaned at $14 \mathrm{~d}$ of age. The initial post-weaning decrease in relative small-intestinal weight may be related to the decline in feed intake in these animals compared with intake during the suckling period. It could also indicate post-weaning morphological gut wall changes, because it was found that all piglets at day 6 had tongue- and leaf-shaped jejunal villi.

The (relative) pancreatic weight of SPC- and SMP-fed piglets increased from weaning until day 10. This is in accordance with the results of Kelly et al. (1991 a) with piglets weaned at $14 \mathrm{~d}$ of age and fed on a diet containing skimmed-milk powder, fish meal and soya-bean meal. Piglets fed on the SBM diet had the lowest relative pancreatic weight at day 3 and piglets fed on the FM diet at day 6 . The low pancreatic weight may be associated with the relatively (although not always significantly) low enzyme activities with the SBMand FM-fed piglets on days 3 and 6 respectively.

\section{Digesta $p H$}

The increase in stomach $\mathbf{p H}$ after weaning is in accordance with the results of Wilson \& Leibholz (1981 $b$ ) and Efird et al. (1982). This result can be explained by post-weaning feed intake pattern and/or the buffering capacity of the post-weaning diets. A high $\mathrm{pH}$ in the stomach could lead to bacterial proliferation (Banwart, 1981) and to disturbance of normal pepsin (EC 3.4.23.1) function (Kidder \& Manners, 1978).

At day 10, piglets fed on the soya-bean diets had lower $\mathrm{pH}$ in gastric contents than piglets fed on the animal protein sources. This could be explained by the buffering capacity of the diets, which was lower for the soya-bean diets (Table 1).

\section{Gastric PP:CP ratio}

The changes in gastric $P P: C P$ ratio after weaning indicate that the degree of gastric protein breakdown is higher for solid diets than for sow's milk. This could be explained by the predominance of chymosin $(E C 3.4 .23 .4)$ compared with pepsin $(E C 3.4 .23 .1)$ activity in 
sucking piglets. Before weaning, coagulation of milk proteins (clot formation) is more important than protein hydrolysis (Cranwell \& Moughan, 1989). Between days 3 and 10 an increase in gastric PP:CP ratio was found, indicating a decrease in gastric protein breakdown and/or an increase in gastric emptying rate of soluble protein.

At day 10 the gastric PP:CP ratio was lower for the FM-fed piglets than for the SPCfed piglets, indicating a higher degree of gastric protein breakdown with the FM diet, since it was suggested earlier that gastric emptying rate was not decreased with the FM diet.

It is clear that the extent of gastric protein hydrolysis depends on age (or time after weaning) and dietary composition (protein source). This was also found by Leibholz (1986) who reported that piglets aged $28 \mathrm{~d}$ had higher stomach $\mathrm{pH}$ and less gastric protein breakdown than older piglets.

\section{Gut wall morphology}

The tongue- and leaf-shaped villi at day 6 are a common finding in newly-weaned piglets (Hampson, 1986; Deprez et al. 1987; Cera et al. 1988). Villus lengths were comparable with those reported by Deprez et al. (1987) of piglets at day 6 after weaning onto a dry diet, and by Hampson (1986) with piglets at day 5 after weaning, and by Miller $e t$ al. (1986) with piglets at 1 week after weaning. Crypt depths were slightly smaller than those reported by Hampson (1986), Miller et al. (1986), Deprez et al. (1987) and Kelly et al. (1991 a).

The positive relationship between jejunal villus lengths and feed intake has been described previously by Kelly et al. $(1991 \mathrm{~b})$. These authors used intragastric-tube feeding to establish different feeding levels in newly-weaned piglets. Villus lengths and crypt depths were positively related to feed intake (Kelly et al. 1991b) as also found in the present experiment. This relationship could indicate a stimulatory effect of feed intake on development of the gut wall.

It was proposed by Gall \& Chung (1982) in rabbits and by Cera et al. (1988) in pigs that low feed intake during the early post-weaning period may be a contributing factor to reduced villus height. However, Kelly et al. (1991 b) also found reductions in villus height in piglets fed through gastric intubation to maintain continuous nutrient supply.

\section{Enzyme activities}

The development of trypsin and chymotrypsin activities in pancreas and jejunum after weaning strongly depended on dietary protein source and post-weaning feed intake. At day 3 , 'non-eaters' apparently stored large amounts of trypsin and chymotrypsin in their pancreatic tissue without substantial secretion into the gut. Intestinal substrate availability seems to be involved in the stimulation of pancreatic trypsin and chymotrypsin secretion as was suggested by DiMagno et al. (1973), Niederau et al. (1986) and Valette et al. (1992). This mechanism is stimulated through the digestive endproducts of intestinal protein digestion (Grendell \& Rothman, 1981; Valette et al. 1992). DiMagno et al. (1973) found that essential amino acids infused into the duodenum or jejunum of humans stimulated pancreatic enzyme secretion. They postulated that the products of protein digestion after absorption inhibit pancreatic enzyme secretion through glucagon release. The study of Niederau et al. (1986) showed that arginine and lysine (the sites of tryptic cleavage) specifically caused the release of trypsinogen in a pancreatic tissue homogenate whereas phenylalanine and tryptophan (sites of chymotryptic cleavage) caused release of trypsinogen and chymotrypsinogen. Valette et al. (1992) found in experiments with pancreas-cannulated growing pigs fed on diets based on either casein or rape-seed that dietary protein source influences pancreatic enzyme secretion. 
Skimmed-milk powder appeared to be the strongest stimulant of trypsin synthesis and secretion during the first $3 \mathrm{~d}$ post-weaning. At day 6 , high pancreatic and jejunal trypsin activities were found with the SPC-fed piglets, while at day 10 the effect of dietary protein source on trypsin activities had disappeared. Feed intake was positively related to pancreatic trypsin activity and therefore might have affected trypsin synthesis.

The interaction between dietary protein source and feed intake during the first $3 \mathrm{~d}$ postweaning with respect to pancreatic chymotrypsin activities is striking. Only piglets fed on FM (i.e. piglets consuming on average more than $100 \mathrm{~g}$ feed/d during the first $3 \mathrm{~d}$ postweaning showed a positive relationship between feed intake and pancreatic chymotrypsin activity.

Piglets fed on the SMP diet had low feed intakes but higher gastric digesta weights compared with piglets fed on the FM diet. This suggests a higher rate of gastric emptying when FM was fed. A faster gastric emptying combined with a higher gastric $\mathrm{pH}$ leads to a more regular supply of more alkaline digesta to the duodenum. From this it can be expected that the pancreas is less challenged to secrete bicarbonate into the gut lumen. This hypothesis is supported by the finding that pancreatic tissue weight was also lower for piglets fed on the FM diet. The low enzyme activities in the jejunum of piglets fed on FM could reflect a lower need for pancreatic enzymes when gastric emptying occurs more gradually (i.e. when the FM diet is fed). It is evident that piglets fed on the FM diet had the highest feed intake during the first $3 \mathrm{~d}$ post-weaning. This could imply a more regular development of feed intake of newly-weaned piglets fed on the FM diet. This regular increase in feed intake after weaning may also imply a better development of the enzyme system, reflected by the positive relationship between feed intake and enzyme activities associated with the FM diet. At day 6 the lowest chymotrypsin activities were found with the FM diet and the highest with the SMP and SPC diets. By day 10 the differences between diets had disappeared, while feed intake was still related to total pancreatic chymotrypsin activity. The trypsin:chymotrypsin ratio in pancreas and jejunum was lower for 'noneaters' than for 'eaters'. This is in accordance with the findings of Corring et al. (1978), Efird et al. (1982), Owsley et al. (1986) and Lindemann et al. (1986) who state that chymotrypsin is the predominant pancreatic protease during the suckling period, while trypsin increases specifically after weaning. Our results indicate that the shift from chymotrypsin to trypsin may be related to post-weaning solid feed intake rather than to weaning itself.

\section{CONCLUSIONS}

During the first $3 \mathrm{~d}$ post-weaning, feed intake was affected by dietary protein source. Dietary FM had a stimulatory effect on the development of post-weaning feed intake, probably related to modifications of gastric emptying patterns which may in turn be related to intestinal protein digestion. SPC diet was associated with high pancreatic tissue weight. Dietary protein source affected the development of trypsin and chymotrypsin activities in pancreatic tissue and jejunal digesta after weaning. Dietary FM generally resulted in low enzyme activities, while SMP and SPC were associated with high enzyme activities. Feed intake during the early post-weaning period clearly stimulated the development of the pancreas and the gut wall.

Dietary buffering capacity, gastric protein hydrolysis and gastric emptying seem to be important factors in the digestion of different protein sources by newly-weaned piglets. From the results presented herein it can be derived that feed intake as well as dietary composition are important factors for the development of the digestive organs of newlyweaned piglets. 
The authors wish to thank $\mathrm{Mr} \mathrm{H}$. Schipper of the Department of Experimental Animal Morphology and Cell Biology for the assistance with the measurement of villus heights and crypt depths.

\section{REFERENCES}

Banwart, G. J. (1981). Basic Food Microbiology. Westport, Connecticut: The AVI Publishing Company.

Bark, L. J., Crenshaw, T. D. \& Leibbrandt, V. D. (1986). The effect of meal intervals and weaning on feed intake of early weaned pigs. Journal of Animal Science 62, 1233-1239.

Bergmeyer, H. U. (1974). Methoden der Enzymatischen Analyse, 3rd ed. Weinheim: Verlag Chemie.

Cera, K. R., Mahan, D. C., Cross, R. F., Reinhart, G. A. \& Whitmoyer, R. E. (1988). Effect of age, weaning and postweaning diet on small intestinal growth and jejunal morphology in young swine. Journal of Animal Science 66, 574-584.

Corring, T., Aumaitre, A. \& Durand, G. (1978). Development of digestive enzymes in the piglet from birth to 8 weeks. Nutrition and Metabolism 22, 231-243.

Cranwell, P. D. \& Moughan, P. J. (1989). Biological limitations imposed by the digestive system to the growth performance of weaned pigs. In Manipulating Pig Production. II. Proceedings of the Biennial Conference of the Australasian Pig Science Association, pp. 140-159 [J. L. Barnett and D. P. Hennessy, editors]. Albury, New South Wales: APSA.

Deprez, P., Deroose, P., Van der Hende, C., Muylle, E. \& Oyaert, W. (1987). Liquid versus dry feeding in weaned piglets: the influence on small intestinal morphology. Journal of Veterinary Medicine B34, 254-259.

DiMagno, E. P., Go, V. L. W. \& Summerskill, W. H. J. (1973). Intraluminal and postabsorptive effects of amino acids on pancreatic enzyme secretion. Journal of Laboratory and Clinical Medicine 82, 241-248.

Efird, R. C., Armstrong, W. D. \& Herman, D. L. (1982). The development of digestive capacity in young pigs: effects of age and weaning system. Journal of Animal Science 55, 1380-1387.

Gall, D. G. \& Chung, M. (1982). Effect of body weight on postnatal development of the proximal small intestine of the rabbit. Biology of the Neonate 42, 159-165.

Grendell, J. H. \& Rothman, S. S. (1981). Digestive end products mobilize secretory proteins from subcellular stores in the pancreas. American Journal of Physiology 241, G67-G73.

Hampson, D. J. (1986). Alterations in piglet small intestinal structure at weaning. Research in Veterinary Science 40, 32-40.

Jensen, A. H. (1966). Pelleting rations for swine. Feedstuffs 38, $24-27$.

Jones, E. E. (1986). Biological development and nutritional requirement of the neonatal pig. Proceedings of the Georgia Nutrition Conference 1986, pp. 145-162. Georgia, USA: University of Georgia.

Kelly, D., Smyth, J. A. \& McCracken, K. J. (1991a). Digestive development of the early-weaned pig. 1. Effect of continuous nutrient supply on the development of the digestive tract and on changes in digestive enzyme activity during the first week post-weaning. British Journal of Nutrition 65, 169-180.

Kelly, D., Smyth, J. A. \& McCracken, K. J. (1991b). Digestive development of the early-weaned pig. 2. Effect of level of food intake on digestive enzyme activity during the immediate post-weaning period. British Journal of Nutrition 65, 181-188.

Kidder, D. E. \& Manners, M. J. (1978). Digestion in the Pig. Bristol: Scientechnica.

Kik, M. J. L., Huisman, J., Van der Poel, A. F. B. \& Mouwen, J. M. V. M. (1990). Pathological changes of the small intestinal mucosa of piglets after feeding of Phaseolus vulgaris beans. Veterinary Pathology 27, 329-334.

Leibholz, J. (1986). Some aspects of digestion in the pig from birth to 56 days of age. Proceedings of the Nutrition Society (Australia) 11, 32-39.

Lindemann, M. D., Cornelius, S. G., El Kandelgy, S. M., Moser, R. L. \& Pettigrew, J. E. (1986). Effect of age, weaning and diet on digestive enzyme levels in the piglet. Journal of Animal Science 62, 1298-1307.

Liptrap, D. O. \& Hogberg, M. G. (1991). Physical forms of feed: feed processing and feeder design and operation. In Swine Nutrition pp. 373-386 [E. R. Miller, D. E. Ullrey and A. J. Lewis, editors]. Boston: ButterworthHeinemann.

Miller, B. G., James, P. S., Smith, M. W. \& Bourne, F. J. (1986). Effect of weaning on the capacity of pig intestinal villi to digest and absorb nutrients. Journal of Agricultural Science, Cambridge 107, 579-589.

Niederau, C., Grendell, J. H. \& Rothman, S. S. (1986). Digestive end products release pancreatic enzymes from particulate cellular pools, particularly zymogen granules. Biochimica et Biophysica Acta 881, 281-291.

Owsley, W. F., Orr, D. E. \& Tribble, L. F. (1986). Effects of age and diet on the development of the pancreas and the synthesis and secretion of pancreatic enzymes in the young pig. Journal of Animal Science 63, 497-504.

Sève, B. \& Laplace, J. P. (1975). Influence de la substitution des protéines du lait par des protéines de poisson sur quelques charactéristiques du contenu gastrique chez le porcelet sevré à 12 jours (Influence of the substitution of milk proteins by fish proteins on some characteristics of the gastric content in the piglet weaned at 12 days). Annales de Zootechnie 24, 43-57.

Souffrant, W. B. (1991). Endogenous nitrogen losses during digestion in pigs. In Proceedings of the Vth International Symposium on Digestive Physiology in Pigs. EAAP Publication no. 54, pp. 147-166. [M.W. A. Verstegen, J. Huisman and L.A. Den Hartog, editors] Wageningen: European Association for Animal Production. 
Statistical Analysis Systems (1990). SAS Procedures Guide, Version 6, 3rd ed. Cary, NC: SAS Institute Inc.

Ternouth, J. H., Roy, J. H. B. \& Siddons, R. C. (1974). Concurrent studies of the flow of digesta in the duodenum and of exocrine pancreatic secretion of calves. 2. The effects of addition of fat to skim-milk and of 'severe' preheating treatment of spray-dried skim-milk powder. British Journal of Nutrition 31, 13-26.

Valette, P., Malouin, H., Corring, T., Savoie, L., Gueugneau, A. M. \& Berot, S. (1992). Effects of diets containing casein and rapeseed on enzyme secretion from the exocrine pancreas in the pig. British Journal of Nutrition 67 , 215-222.

van Baak, M. J., Rietveld, E. C. \& Makkink, C. A. (1991). Determination of trypsin and chymotrypsin activity in pancreatic juice: the effect of freeze-drying and storage. In Proceedings of the Vth International Symposium on Digestive Physiology in Pigs. EAAP Publication no. 54, pp. 356-360 [M.W. A. Verstegen, J. Huisman and L. A. den Hartog, editors]. Wageningen: European Association for Animal Production.

Wilson, R. H. \& Leibholz, J. (1981 a). Digestion in the pig between 7 and 35 days of age. 1. The performance of pigs given milk and soya-bean proteins. British Journal of Nutrition 45, 301-319.

Wilson, R. H. \& Leibholz, J. $(1981 \mathrm{~b})$. Digestion in the pig between 7 and 35 days of age. 2 . The digestion of dry matter and the $\mathrm{pH}$ of digesta in pigs given milk and soya-bean proteins. British Journal of Nutrition $45,321-336$.

Wilson, R. H. \& Leibholz, J. $(1981 c)$. Digestion in the pig between 7 and 35 days of age. 3. The digestion of nitrogen in pigs given milk and soya-bean proteins. British Journal of Nutrition 45, 337-346. 